\title{
Popular responses to mamluk fiscal reforms in Syria
}

\author{
Bethany J. Walker
}

\section{(2) OpenEdition \\ 1 Journals}

Electronic version

URL: http://journals.openedition.org/beo/60

DOI: $10.4000 /$ beo.60

ISBN: 978-2-35159-316-5

ISSN: 2077-4079

Publisher

Presses de l'Institut français du Proche-Orient

Printed version

Date of publication: 1 September 2009

Number of pages: $51-68$

ISBN: 978-2-35159-143-7

ISSN: 0253-1623

\section{Electronic reference}

Bethany J. Walker, «Popular responses to mamluk fiscal reforms in Syria », Bulletin d'études orientales

[Online], Tome LVIII | Septembre 2009, Online since 01 September 2010, connection on 19 April 2019. URL : http://journals.openedition.org/beo/60 ; DOI : 10.4000/beo.60 


\title{
POPULAR RESPONSES TO MAMLUK FISCAL REFORMS IN SYRIA
}

\author{
Bethany J. WALKER
}

Department of History, Missouri State University

The decline of the Mamluk state - its character, timing and evolution, and the catalysts behind it - has been one of the most debated topics in Mamluk studies. Sparked by the publication of Amalia Levanoni's monograph on Sultan al-Nasir Muhammad in 1995, scholarship on the issue has largely focused on identifying when and under what conditions the Mamluk "machine" began to fail politically, militarily, and economically. ${ }^{1}$ The changes in Egyptian and Syrian society that followed in its wake have only begun to be explored, as Mamluk "decline" has been in recent years reinterpreted in terms of social and political "transformations". ${ }^{2}$ On the level of the economy, the parameters of debate have shifted to state responses to crises, specifically policy changes aimed at redeeming the Treasury and staving off bankruptcy. Such is a revisionist understanding of the late Mamluk period that defines economic action, in part, as rational response to economic necessity. An earlier emphasis on exploitative attempts to line individual pockets or replenish the Treasury (through confiscation, hoarding, and devaluation of currency) is being gradually replaced with an appreciation of more long-term initiatives that would accomplish the same, such as the creation of new financial bureaus and structures for developing private property. Thus, greed may have been less a motivator for some of the financial practices of the fifteenth century than economic imperatives. While current scholarship far from suggests that the elite of the Mamluk state, as a whole, governed with wisdom in the economic sphere, it is illustrating ways in which individual actors did attempt meaningful reforms with an eye to financial recovery and long-term stability.

What has been missing from these debates to this point, however, has been a consideration of how the non-elite responded to these initiatives and how they perceived the changes that resulted from them in their own societies. This essay explores one economic practice actively discussed, and criticized, by contemporaries: the purchase of Treasury

1. A Turning Point in Mamluk History: The Third Reign of al-Nasir Muhammad ibn Qalawun (1310-1341) (Leiden, 1995).

2. To cite one example of such exchanges, a panel devoted to the topic at the annual International Conference on Medieval Studies in Kalamazoo, Michigan in May, 2005 was published in 2007 in a special issue on Mamluk economics in Mamluk Studies Review (volume 11.1). 
(Bayt al-Mal) assets and their subsequent endowment (waqf). As one of the most important economic developments of the late Middle Ages in the Islamic world, the alienation of public lands and their transformation into private property is an important turning point in medieval Islamic financial history. Similarly, the legal mechanisms that emerged, legitimizing both practices, mark an important development in Hanafi thought and are recognized as a watershed in the larger history of Islamic jurisprudence. Such practices had not only economic and legal repercussions; they had the potential to transform the agricultural regime, and local society in a more general sense, as land proprietorship and management were the ties that bound both the countryside and urban centers to the state.

The following offers some reflections on popular responses to the alienation of Treasury assets in the fourteenth and fifteenth centuries, by examining the political action by peasants, the critiques of local intellectuals, and the formal opinions of lawyers. ${ }^{3}$ The study makes special reference to Jordan in this period, as the building of sultanic landed estates from former state lands appear to have been first applied on a large scale in the Transjordan. ${ }^{4}$ Jordan thus becomes a barometer of the success or failure of one aspect of the Mamluks' fiscal reforms and offers a window on the ways in which they played out on the local level. In order to describe the background of the reforms, we begin with contemporary critiques of the economy.

\section{CONTEXT OF FINANCIAL REFORMS}

Contemporaries were well aware of the financial problems of the day and were quick to blame an ineffective, corrupt, and apathetic government for inefficient, or non-existent, responses to rising prices and food shortages. Perhaps the most vocal critic of the Mamluk state's fiscal policies was the Egyptian historian Taqi al-Din Ahmad ibn 'Ali ibn 'Abd alQadir ibn Muhammad al-Maqrizi. He completed his treatise on famine (Ighathat al-ummah bi-kashf al-ghummah) in 1405, at the end of his third term as Inspector of the Markets in Cairo. In this work he captures the realities of life for most Cairenes at the turn of the fifteenth century: people were going hungry, and food, though available, was not being distributed. He points to several practices, with which he was intimately familiar, that created scarcities of foodstuffs and exacerbated their effect: inflated prices and forced purchases (tarh) by officials, bribery (particularly damaging when financial offices are purchased in this manner), high taxes, and an unstable and inflated currency. ${ }^{5}$ Although he recognizes that several seasons of draught caused initial food shortages, he blames the state for not appropriately responding to the agricultural crisis that ensued and for corruption and poor financial practices that made it much worse.

3. This article pulls from ideas more fully developed in Chapter Four in my forthcoming monograph Jordan in the Late Middle Ages: Transformation of the Mamluk Frontier.

4. Mamluk "Jordan" consisted of the Province (Mamlakat) of Kerak and the southernmost district of the Province of Damascus.

5. Adel Allouche, Mamluk Economics: A Study and Translation of al-Maqrizi's Ighathah (Salt Lake City, 1994, 50-54. alMaqrizi wrote a second book, devoted entirely to currency devaluation: Shudhur al-uqud fi dhikr al-nuqud. 
A much lesser known source, Muhammad ibn Khalil al-Asadi, responds in a similar tone about the economic functions of the state in his treatise on administrative and financial reform (al-Taysir wa al-itibar wa al-tahrir wa al-ikhtibar fi-ma yajibu min husn al-tadbir wa altasarruf wa al-ikhtiyar), written around $854 / 1450 .{ }^{6}$ While he devotes the largest part of this work to inflation and monopolies, he makes several suggestions for economic revival that require decisive action by the government. For him, it is the responsibility of the state to control the value of currency, guarantee unrestricted markets, and ensure the availability of basic foodstuffs. His perspective, which betrays a background in the Syrian financial administration, is comparable to that of al-Maqrizi in its identification of manipulation of currency, corruption and tyranny of officials, the imposition of illegal and high taxes, and neglect of agricultural lands as the factors behind the poor economic conditions of the state in his day. ${ }^{7}$

Though valid, the critiques of al-Maqrizi and al-Asadi are more concerned with the effects than the causes of the economic malaise of the fifteenth century. The Mamluk state was, in fact, at the verge of financial collapse by the end of the fourteenth century, a state of affairs that Sultan Barquq immediately tried to address, first in his office as atabeg and then as sultan (reigned 784-791/1382-1389, 792-801/1390-1399), the first of the Burji, or socalled "Circassian", dynasty. ${ }^{8}$ Barquq's sultanate has been increasingly attracting scholarly attention for more than merely political change, as it also coincides with attempts to revive, or replace, the moribund iqta' system. ${ }^{9}$ The iqta' system - which controlled most of the agricultural land in Egypt and Syria and organized the distribution of tax revenues from those lands to the military - was the backbone of the Mamluk economy and structured economic, political, and social relations among the state, the cities, and the countryside. It was no longer functioning effectively by the end of the century, as the Treasury had been gradually drained of the landed assets on which iqta grants were based. ${ }^{10}$ The leasing and sale of land from the Bayt al-Mal had become more common in the second half of the fourteenth century, following the demographic and economic turmoil of the Black Death

6. The work has been published under this title and edited by 'Abd al-Qadir Ahmad Tulaymat (Cairo, 1968). (Though long out of print, the occasional copy can be found in Cairo through the publisher, Dar al-Fikr al-'Arabi.) There have been very few scholarly studies of the work. Some notable early ones include Muhammad Kurd 'Ali, "alTaysir wa al-I'tibar wa Tahrir al-Ikhtiyar fi-ma Yajibu min Husn al-Tadbir wa al-Tasarruf wa al-Ikhtiyar”, Majallat Majma' al-Lughah al-Arabiyyah bi-Dimashq 3.11 (1923): 321-327 and Subhi Labib, "al-Asadi und sein Bericht über Verwaltungs- und Geldreform im 15. Jahrhundert", Journal of Economic and Social History of the Orient 8 (1965): 312-316. For more recent analysis of the text, see John L. Meloy, "The Privatization of Protection: Extortion and the State in the Circassian Mamluk Period", Journal of Economic and Social History of the Orient 47 (2004): 195-212 and ibid, "Himayah", Chicago On-line Encylopaedia of Mamluk Studies (accessed at http://mamluk.uchicago.edu).

7. 'Ali, “al-Taysir wa al-I'tibar", 198.

8. DAISUKE IGARASHI, "The Establishment and Development of al-Diwan al-Mufrad: Its Background and Implications”, Mamluk Studies Review 10.1 (2006): 121-122.

9. The cultivation of networks of political patronage that, in part, brought Barquq to power is briefly explored in Jo Van Steenbergen, Order Out of Chaos: Patronage, Conflict and Mamluk Socio-Political Culture, 1341-1382 (Leiden, 2006). For his administrative and economic reforms as sultan, see Igarashi, "The Establishment and Development of alDiwan al-Mufrad", 117-140 and Bethany J. Walker, "Sowing the Seeds of Rural Decline? Agriculture as an Economic Barometer for Late Mamluk Egypt”, Mamluk Studies Review 11.1 (2007): 173-199, a discussion of which follows.

10. IBn QAdi ShuHba, Tarikh Ibn Qadi Shuba, ed. Adnan Darwish (1977) 1: 225. 
and the coming to power of a series of weak sultans. The death of grant holders (muqta's), accelerated by the plague, made numerous tax revenues (and the lands that supported them) available, a circumstance of which advantage could be taken in the absence of a strong, and watchful, central government.

Not surprisingly, iqta' grants, which would normally be distributed to new personnel upon the death of its muqta, and other kharaj-paying lands were being sold, at generally lower prices than they were worth, in order to liquidate assets and secure cash for political purposes. ${ }^{11}$ The land then became, for all intents and purposes, the private property of the purchaser, leaving the Treasury for good and no longer available for soldiers' compensation. ${ }^{12}$ Moreover, such land was frequently made waqf for a charitable endowment, which was taxfree, could not be legally confiscated, and which normally benefited the descendants of the donor, as trustees of the foundation. While lucrative for individuals (who were, more often than not, members of the Mamluk and civilian elite) and their families, the alienation of Treasury assets in this manner robbed the state of important revenues for defense, social services, and emergencies of all forms. ${ }^{13}$ State officials, starved of funds in this manner, resorted to the kinds of damaging, and illegal, practices lamented by al-Maqrizi and alAsadi in an effort to replenish salaries and, undeniably, build personal wealth.

Igarashi's recent studies on the fiscal reforms of Sultans Barquq (d. 801-1399) and Qaytbay (ruled 872-901/1468-1496) highlight the central role the "waqfization" of public assets played in the financial crises of the late fourteenth and fifteenth centuries. He convincingly argues that attempts at economic recovery specifically targeted this phenomenon and tried to rectify it by finding ways to legalize confiscation of endowed properties and institutionally bypass long-standing bureaus that traditionally controlled access to state assets. To summarize Igarashi's arguments, the depletion of the Treasury, and specifically the revenues from kharaj-paying lands, caused a financial crisis at the outset of Barquq's reign, by robbing the state of resources from which to pay the military, and particularly the Royal Mamluks. He responded by creating two new financial bureaus that would be under his direct control as sultan: al-Diwan al-Mufrad (likely established in 1386) and Diwan al-Amlak (in 1395)..$^{14}$ The first, originally financed from his personal assets (his own iqta's), would be dedicated to the financial support of the Royal Mamluks, independent of the other diwans and funded separately from the rest of the Treasury. By the mid-fifteenth century, this bureau came to control the largest percentage of kharaj-

11. See Van Steenbergen, Order out of Chaos, 57-75 for an assessment of the role of money in the political struggles of the late Bahri period.

12. There is a growing body of scholarship on this topic. In addition to Igarashi's work cited above ("al-Diwan al-Mufrad"), see Khalil 'Ashaminah, Filistin fi al-'Ahadayn al-Ayyubi wa al-Mamluki (1187-1516) (Beirut, 2006): 357-361, Walker, "Sowing the Seeds", and the work by Petry and Abu Ghazi reviewed below. 'Ashaminah documents the "privatization" of state assets in a similar manner by retirees and those dismissed (turkhan and battal) from military service.

13. For examples of the ways Treasury assets met emergencies in Syria, see Ibn Qadi Shuhba, Tarikh, 1:517 (in 796 Sultan Barquq requested one-half of the village of al-Aftarisi from the Treasury in order to equip the army to check the advance of Timur on Syria) and 555 (in 797 wheat from the Treasury was sold to feed orphans and others in need).

14. Igarashi, "al-Diwan al-Mufrad". 
paying lands in Egypt. Syrian land also came under the authority of this bureau, although we cannot know for sure, in the absence of written documentation of land surveys in Syria (comparable to Ibn Duqmaq and Ibn Ji'an), to what extent it was applied. ${ }^{15}$ This, thus, marks an important stage in the reorganization of the state's administrative and economic apparatus. The success of Barquq's initiatives in concentrating assets may be gauged by the settlement of his estate upon his death: in 801 a meeting of leading clerics, high-ranking amirs, and the Khassakiyya debated who would be entitled to his vast assets, agreeing that $5 / 6$ would return to the Treasury, where they "would be spent for the benefit of [all] Muslims" (yusarraf fi mașalih al-muslimin). ${ }^{16}$

Igarashi demonstrates that al-Diwan al-Mufrad, over time, came to be something of a social welfare institution for the non-mamluk members of the elite: mamluks' widows and sons (awlad al-nas), lawyers, and merchants. ${ }^{17}$ As a result, because expenditures outstripped the assets of the bureau, it was at a state of virtual bankruptcy by the reign of Qaytbay (r. 872901/ 1468-1496). The state's finances were further strained by expensive military campaigns against the Ottomans. Sultan Qaytbay responded by using his own assets (khass and his endowments), as well as those of other bureaus, to sustain al-Diwan al-Mufrad and to pay amirs and continue pensions. Such efforts were reinforced with other measures meant to replenish the Treasury, such as taxation of endowments, taking $1 / 5$ of kharaj revenues from iqta's, and freezing subsidies to non-mamluks. The ultimate result was the transformation of the Treasury into a financial agent of the sultan, furthering the process of centralization of state funds and highlighting most clearly the demise of the feudal iqta' system. ${ }^{18}$

The reforms of Qaytbay built on those of Barquq and had the same goal: to put money back into the Treasury, or at least under the centralized and direct control of independent bureaus controlled by the sultan, for redistribution to his own mamluks and where else most needed. It is ironic, however, that the practice that initially led to the crisis of the Treasury - the alienation of former iqta lands from the Treasury and subsequent endowment for family or charitable foundations - was one adopted, in the end, for financial recovery. This was, as well, the economic practice most debated in legal circles and which had the greatest potential to transform imperial-rural relations and the agricultural sector.

\section{“WAQFICATION” OF THE TREASURY (BAYT AL-MAL)}

The endowment of privately-owned, income-producing properties for public good (waqf) was considered an act of piety and supported, as all charities, by Shari'a. The act of endowment took the property out of the public sphere: the ownership of the property itself (the 'ayn) now belonged to God, its revenues were earmarked for a charitable purpose,

15. Al-Diwan al-Mufrad controlled, as well, lands in Syria. As early as $800 \mathrm{H}$ the office of Hajib al-Sham was also responsible for the revenues of al-Diwan al-Mufrad, and two years later the deputy of the majordomo ( $N a^{\prime} i b$ alustadar) of Syria fulfilled this role (Ibn Qadi Shuhba, Tarikh 1: 657 and (1997) 4: 107). For a discussion of Ibn Duqmaq's Kitab al-intisar li-wasitat 'iqd al-amsar and Ibn Ji'an's Kitab al-tuhfah al-saniyah bi-asma' al-Bilad al-Misriyah, from a Syrian perspective, see Walker, "Sowing the Seeds", 178-179.

16. IBn QAdI SHuHBa, Tarikh 4: 25-26.

17. DaisuKe Igarashi, “al-Diwan al-Mufrad”, 132-137 - citing al-Maqrizi and Ibn Taghribirdi.

18. Daisuke Igarashi, “Financial Reforms of Sultan Qaytbay”, Mamluk Studies Review 13.1 (2009): 27-51. 
and it could no longer be taxed or otherwise legally touched by the state. A second form of endowment - family waqf - was equally legal but not as secure as a charitable one, as its revenues were set aside for the benefit of a family and its descendants. They were particularly vulnerable to confiscation by government officials. Mamluk-era endowments fell into both categories: charitable awqaf (awqaf khayri) could be administered by the endower and his family (who could then enjoy a portion of the revenues as compensation), and formal family awqaf (awqaf dhurri or ahli) would generally ultimately benefit a charitable cause or foundation when the family line died out. Of the former, the largest were "sultanic endowments", which were either created directly from Treasury (in other words, public, kharaj-liable) lands, supporting institutions in the general interest (maslaha) of the Muslims, or indirectly through quasi-legal purchase of iqta'at and other lands from the Treasury, subsequently endowed for charitable purposes (either explicitly or indirectly) through formal legal procedures. ${ }^{19}$ In principle, the former were legal, while the legality of the latter (discussed below) was intensely debated among fifteenth-century jurists. ${ }^{20}$ Sultanic endowments ultimately served the larger good of the community, because they frequently funded expensive and important public services (health care, education, building of mosques, supplying water); they were, nonetheless, the biggest financial liability for the Mamluk state. Any alienation of taxable public lands robbed the state of critical funds needed for defense, development, emergencies, and support for the poor.

Critical analyses of awqaf by Carl Petry and 'Imad Abu Ghazi have brought attention to the financial and political impact of the "waqfization" of former public lands. ${ }^{21}$ Petry was the first to identify the "privatization" of state lands as a kind of "clandestine investment" during the financial crises of the late Mamluk period. ${ }^{22}$ What resulted was both the final death blow of the iqta' system, the socio-political-economic underpinning of the Mamluk state, and asset-building in the form of private property: in short, the reemergence of

19. Such endowments in Mamluk-period sources are simply referred to as awqaf made by the ruler (imam, sultan) from the Bayt al-Mal, but in Ottoman sources in Syria and Egypt they came to be known as waqfirsadi (or "endowment of designation"), if they came directly from the Treasury (Kenneth M. Cuno, "Ideology and Juridical Discourse in Ottoman Egypt: The Uses of the Concept of Irsad”, Islamic Law and Society 6.2 (1999), 141).

20. Technically the sultan, as the head of state, could not legally sell public lands to himself, although he could endow directly from the Treasury (according to some contemporary scholars). In order to purchase from the Treasury, he would assign a civilian agent (wikalat Bayt al-Mal) to act on behalf of the Treasury and to sell to him the land, or, in his capacity of head of the government, the sultan would personally sell from the Treasury to a third party, later buying the same property from him (Kenneth Cuno, "Was the Land of Ottoman Syria Miri or Milk? An Examination of Juridical Differences within the Hanafi School", Studia Islamica 81.1 (1995), 126, note 19). On wikalat Bayt al-Mal, see Yusuf Ghawanmeh, Dimashq fi 'Asr Dawlat al-Mamalik al-Thaniyah (Beirut, 2005), 94.

21. Carl F. Petry, Protectors or Praetorians? The Last Mamluk Sultans and Egypt's Waning as a Great Power (Albany, 1994): 196-210; idem, "Fractionalized Estates in a Centralized Regime: The Holdings of al-Ashraf Qaytbay and Qansuh alGhawri According to their Waqf Deeds", Journal of Economic and Social History of the Orient 41.1 (1998): 95-117; idem, "Waqf as an Instrument of Investment in the Mamluk Sultanate: Security vs. Profit?", in Slave Elites in the Middle East and Africa: A Comparative Study, ed. Toru Miura and John Edwards Philips (New York, 2000), 99-115; and 'Imad Badr al-Din Abu Ghazi, Fi Tarikh Misr al-Ijtima ii: Tatawwur al-Hiyazah al-Zira'iyah Zaman al-Mamalik al-Jarakisah (Dirasah fi Bay" Amlak Bayt al-Mal) (Cairo, 2000).

22. Because the endowments of Sultans Qaytbay and al-Ghawri (r. 906-922/1501-1516) produced revenues that exceeded expenditures by over $90 \%$, it would appear that their primary purpose was revenue production, rather than support of charities (Petry, "Waqf as an Instrument", 104). See also Petry, Protectors or Praetorians?, 210. 
private property after the collapse of the Mamluk-style feudal system. Petry estimates that some $30 \%$ of the Mamluk endowments registered in the waqfiyat of the Cairo archives date to the reign of Sultan al-Ghawri, ${ }^{23}$ suggesting a response to economic or political pressures at the end of the Mamluk era. Most of these, according to the documents available, were acquired piecemeal, as shares of rural land or villages. ${ }^{24}$ In his quantitative analysis of waqfiyat and documents of sale, purchase, and transfer in Egyptian archives, Abu Ghazi determines, in parallel fashion, that most of the pre-Ottoman endowments in Egypt (over 95\%) date to the Burji Mamluk period (and the majority of these during the reigns of Sultans Inal, Khushqadam, Qaytbay, and al-Ghawri) and that they were made from the purchase of iqta land. ${ }^{25} \mathrm{He}$ concludes that by the end of the Mamluk Sultanate, the Treasury was, for all intents and purposes, empty, a condition largely produced by the endowment of nearly $90 \%$ of Egypt's agricultural land. ${ }^{26}$

The history of endowments in Jordan challenges this scenario. Mamluk-era waqfiyat in the Dar al-Watha'iq and Wizarat al-Awqaf in Cairo, the majority previously unidentified, ${ }^{27}$ and sixteenth-century Ottoman tax registers (tapu defters) for Liwa' Ajlun in Ankara, now published, document the endowment of entire villages in Jordan by sultans as early as the reign of Sha'ban (r. 764-778/1363-1377) ${ }^{28}$ and the development of sultanic landed estates, through waqf, of Jordanian agricultural land from Barquq's reign. ${ }^{29}$ They largely benefited the madrasa complexes of the donor-sultans in Cairo. Many of these endowments were maintained by the Ottoman authorities (and taxed at 10\%, as most local awqaf were under the Ottomans) incorporated, in their entirety, into the khass of the sultan or provincial governor. Sultanic endowments in Jordan were among the most lucrative in the region (sugar plantations, expansive wheat fields, well watered olive groves) and include the entire

23. Petry, "Waqf as an Instrument", 105.

24. Ibid., 103.

25. Abu Ghazi, Fi Tarikh Misr, 16-22.

26. Ibid., 83.

27. Preliminary studies can be found in Yousef Ghawanmeh, "al-Qarya fi Junub al-Sham (al-Urdunn wa-Filistin) fi al-'Asr al-Mamluki fi Daw' Waqfiyat Adar", Studies in the History and Archaeology of Jordan 1 (1982): 363-371 and idem Tarikh Sharqi al-Urdunn fi 'Asr Dawlat al-Mamalik al-Ula (al-Qism al-Hadari) (Amman, 1979), 243-244; Bethany J. Walker "Mamluk Investment in the Transjo privately-held rdan: A 'Boom and Bust' Economy”, Mamluk Studies Review 8.2 (2004): 119-147 and idem, "The Northern Jordan Survey 2003 - Agriculture in Late Islamic Malka and Hubras Villages: A Preliminary Report of the First Season", Bulletin of the American Schools of Oriental Research 339 (2005): 67-111. The comprehensive analysis of these documents, in addition to other waqfiyat, appears in Walker, Jordan in the Late Middle Ages.

28. For references to portions (or shares) of Jordanian villages and agricultural lands endowed much earlier by Sultan al-Zahir Baybars (r. 658-676/1260-1277), see Ghawanmeh, "al-Qarya fi Junub al-Sham", 371 (one-half of the village of al-Tura, in northern Jordan - citing Taqi al-Din al-Subki) and Muhammad Adnan al-Bakhit and Noufan Raja Hmoud, al-Defter al-Mufassal li-Liwa' 'Ajlun, Tapu Defteri No. 185, Ankara 1005 A.H./1596 A.D. (Amman, 1991), 32 (shares in the village of Bayt Rama, in the Jordan Valley).

29. The relevant registers have been edited and published, in Turkish with Arabic commentary, in Muhammad Adnan al-Bakhit, Nahiyat Beni Kinana (Shamali al-Urdunn) fi al-Asr al-Ashir al-Hijri/al-Sadis 'Ashir al-Miladi (Amman, 1989) and al-Bakhit and Hmoud, Tapu Defteri 185. Brief summaries of a handful also appear in Mehmet Ipsarli and Muhammad Dawud al-Tamimi, Awqaf wa Amlak al-Muslimin fi Filistin (Istanbul, 1982). 
village of Adar and miscellaneous gardens (all near Kerak - by Sha'ban in 777/1375) ${ }^{30}$; the villages of Nimrin, Kafrin, and Zara'a (all in the Jordan Valley) and Malka (in the north), all in their entirety (by Barquq in 796/1393); the northern villages of Marw and Harhar and shares of several villages in the northern hill country and Jordan Valley (by Khushqadam [r. 865-872/1461-1467], no date given); and the village of Majid, also in the north (by Qaytbay, no date given). ${ }^{31}$

The extant Mamluk waqfiyat and Ottoman tax registers that confirm these endowments do not generally specify under what circumstances and through what legal means these lands were initially acquired. The waqfiyah for Sultan Sha'ban's endowment of gardens, water facilities, and a bathhouse (hammam) in Adar does mention that the properties were "from the land in the government's domain" (min al-khass al-sharif); this reference is, however, a rare exception. ${ }^{32}$ The availability of so many villages, in their entirety rather than mere shares, in Jordan in the mid-fourteenth century may be related to the demographic and administrative turmoil caused by the plague of the 1340s, as the sultan, and other members of the ruling elite, appropriated the iqta at of plague victims. ${ }^{33}$ Until purchase documents for such villages are identified in the archives, one must assume they were endowed by sultanic fiat from the Treasury or through sale from the same, transforming the land to milk (private property), and subsequently endowed.

Purchases of properties from the Treasury and endowments by amirs can be identified even earlier in Jordan. ${ }^{34}$ Amman and Hisban present a particularly interesting case for the former. The village of Hisban, located some twenty kilometers south of Amman on the Madaba Plains, served as the district capital of the Balqa during the first half of the fourteenth century. It housed a small garrison of soldiers, led by an amir of ten, and had a prosperous market, its own court and judge (qadi), and a madrasa. In 757/1357 the amir Sarghatmish purchased the entire "city" (madina) of nearby Amman from the Bayt al-Mal, presumably for the benefit of his madrasa complex in Cairo, built the same year, although this is not specified by Ibn Qadi Shuhba. ${ }^{35} \mathrm{He}$ subsequently moved all important public services from Hisban to Amman, including the local administration, judiciary, and market,

30. In addition to properties on the Kerak Plateau, this endowment included many whole villages in Egypt and Syria, including those in the region of Hama, Ma'arat al-Nu'man, Nablus, and Aleppo (Ghawanmeh , "al-Qarya fi Junub al-Sham", 367).

31. Walker, "Sowing the Seeds", 189-190; idem, "Boom and Bust"; and Muhammad Adnan al-Bakhit, "Awqaf During the Late Mamluk Period and Early Ottoman Times in Palestine and Jordan", in Urbanism and Islam, ed. Editorial Committee of the Research Project "Urbanism in Islam, a Comparative Study" (Tokyo, 1994), 188.

32. Waqfiyah 8/49, Dar al-Watha'iq, Cairo - transcribed in Ghawanmeh, Tarikh Sharqi al-Urdunn, 243.

33.The rural properties endowed for Sultan al-Nasir Hasan's madrasa complex (work begun in 758/1357) in Rumayla, near the Cairo Citadel, were likely acquired under these circumstances (Howayda N. al-Harithy, "The Complex of Sultan in Cairo: Reading Between the Lines", Muqarnas 13 (1996), 69).

34. For amiral awqaf in Ajlun, see Yusuf Ghawanmeh, "al-Tijarah fi al-Urdunn fi al-'Asr al-Mamluki”, Studies in the History and Archaeology of Jordan 3 (1987): 323-330.

35. There appears to be no reference to Amman or any of its lands in Sarghatmish's waqfiyah of 757/1356 (Waqfiyah 3195, Wizarat al-Awqaf, Cairo) for this madrasa in Rumayla. The document has been partially published by 'Abd alLatif Ibrahim in his "Nassan Jadidan min Wathiqat al-Amir Sarghatmish", Bulletin of the Faculty of Arts, University of Cairo 27 (1965): 121-158. 
as well as a large number of the residents of the village, and invested in new constructions, making Amman the new district capital. ${ }^{36}$ In the following forty years, Amman passed from Sarghatmish to his officer Amir Bulut and subsequently parts of its land to Sultan Barquq's Viceroy, amir Sudun al-Shaykhuni, who financially invested in it. In 797 Amman was sold by Amir Bulut's heirs to the Governor of Syria. ${ }^{37}$ Hisban, in the meantime, experienced a bit of a renaissance with som resettlement of the town an reuse of the citadel. Endowments of this sort may have played a special role in the administrative structure of Mamluk Jordan, as amiral and sultanic sponsorship of local centers molded the economic and political fortunes of places and peoples. ${ }^{38}$

\section{POPULAR RESPONSES}

Few villages or towns were impacted as directly as Hisban as a result of sales of Treasury land: Hisban seems to be an isolated incident of forced population transfer. In most villages, regardless of their status as an iqta', milk, or waqf, the management of farmland was largely in local hands; only on the most prosperous rural endowments were state officials more actively involved in the affairs of the estate and local society. The responses of local peoples to the endowment of state lands in their region, and other government initiatives in the countryside, are reflected in the actions of peasants and commentaries on state initiatives by that segment of local society that gave them voice in the contemporary sources: the local intelligentsia.

\section{Peasants and the local historians}

The political perspectives of peasants are not easily reconstructed from the kinds of written sources available. Outside of the legal depositions and court records preserved in the fourteenth-century Haram al Sharif collection in Jerusalem, ${ }^{39}$ we have yet to identify for the Mamluk period the numerous formal petitions to the Shari'a courts available for Ottoman Jerusalem or correspondences with officials that can be found for the early-mid twentieth century. ${ }^{40}$ However, some sense of their attitudes towards the state, particularly

36. Archaeological excavations at Hisban have revealed the abandonment of the citadel in the mid fourteenth century. Initial analysis of the remains of the "governor's palace" indicate that it was quickly abandoned after an earthquake (Bethany J. Walker and Øystein S. LaBianca, "The Islamic Qusur of Tall Hisban: Preliminary Report on the 1998 and 2001 Seasons", Annual of the Department of Antiquities of Jordan 47 (2003): 443-471.

37. Ibn Qadi Shuhba, Tarikh, 1:550.

38. On this theme, see Bethany J. Walker, "Mamluk Investment in Southern Bilad al-Sham in the Eighth/Fourteenth Century: The Case of Hisban”, Journal of Near Eastern Studies 62.4 (2003): 241-261.

39. For the contents of these documents, which arealso preserved on microfilm in the Bilad al-Sham Center of the University of Jordan, see Donald P. Little's A Catalogue of the Islamic Documents form al-Haram as-Sarif in Jerusalem (Beirut, 1984).

40. Amy Singer, in her Palestinian Peasants and Ottoman Officials: Rural administration around sixteenth-Century Jerusalem (Cambridge, 1994), makes effective use of the former for early Ottoman Palestine. For examples of the latter - letters to the Ministry of Endowments of Jordan - see Bethany J. Walker, Ellen Kenney, Laura Holzweg, Lynda Carroll, Stéphanie Boulogne, and Bernhard Lucke, "Village Life in Mamluk and Ottoman Hubras and Saham: Northern Jordan Project, Report on the 2006 Season", Annual of the Department of Antiquities of Jordan 52 (2007), 433, 446. 
in affairs relating to natural resources, can be gauged by their political activism (in its myriad forms) and critiques of state action, as described and transmitted by local historians. Syrian chroniclers, many of whom maintained personal and professional networks in the communities they describe, speak, in this sense, on behalf of the peoples of rural Bilad alSham.

According to these historians, the practices of the Mamluk state that drew the strongest reactions from the countryside were interference of officials in traditional land management, hoarding or confiscation of grains, and ineffective crisis management. Water sharing, crop rotation, and the process of land preparation and harvest were generally guided by local custom; the state rarely intervened in any of these activities. When it did, local response could be remarkably swift and effective. One particularly vivid example of conflict between a state official and Jordanian peasants, in this regard, is related by Ibn Qadi Shuhba in his annal of 799/1396. ${ }^{41}$ Iyas al-Jarkashi, while Supervisor of the Jordan Valley (mushadd al-Aghwar) under Sultan Barquq, infuriated local farmers by diverting shared water to his own plantations in the region, forcing sales of his own sugar at inflated prices (tarh) on local residents, and terrorizing the population at large by cutting the hands off accused thieves. After numerous complaints by local peasants and administrators alike for his abuses, the sultan had him arrested and killed that year. When the actions of officials or the military led to general suffering, in the form of famine or widespread destruction of property, rural communities were capable of much more than filing complaints. Syrian historians with a knowledge of, and personal concern for, Jordanian villages (such as Ibn Qadi Shuhba, Ibn Sasra, and Ibn Hijji) describe peasants taking up arms or abandoning their homes and farms when their food, animals and supplies were confiscated or collective punishment was inflicted upon them during the political unrest of the early fifteenth century. ${ }^{42}$

Interference in resource management, theft, and violence by state officials immediately created tensions with rural communities. Most financial practices, however, would have been largely invisible to local people, such as the inner workings of the Mamluk Treasury and the endowment system. There is nothing in written sources to suggest that peasants or pastoralists were aware of the changes of the day in state land management. While sultanic and amiral endowments undoubtedly did public good - even al-Maqrizi credited Sultan Barquq's endowments with preventing widespread famine by feeding people - most of the large, endowed institutions (madrasas, hostels) were located in big towns outside of Jordan. ${ }^{43}$ As for the land that supported them, revenues were collected in essentially the same manner as before endowment; peasants' lives continued as they always had. It should be emphasized that only the creation of large estates dedicated to cash crops, as in the case of Iyas al-Jarkashi, caused potential conflict. Accumulation of vast expanses of agricultural

41. Ibn Qadi Shuhba, Tarikh, 1: 630-631.

42. Bethany J. Walker, "The Role of Agriculture in Mamluk-Jordanian Power Relations", in Exercising Power in the Age of the Sultanates: Bilad al-Sham and Iran, ed. B.J. Walker and Jean-François Salles, Bulletin d'Études Orientales, supplement 67 (2007): 77-96 ; Shawkat Ramadan Hijjah, al-Tarikh al-Siyasi li-Mintaqat Sharq al-Urdunn (min Junub alSham) fi 'Asr Dawlat al-Mamalik al-Thaniyah (Irbid, 2002), 128-136.

43. Allouche, Mamluk Economics, 53. 
land would have led to more centralized management and brought the state into more active engagement with local communities, although this is an area of inquiry that needs to be more fully explored.

On the other hand, how the state handled environmental, demographic, or economic crises (caused by drought, flood, disease, or military incursions by foreign forces, for example), and the oppression and corruption of officials were issues of greater concern in the larger towns of Syria. For Damascus-based scholars with ties to the Jordanian countryside, like Ibn Hijji, misappropriation of waqf funds were signs of the corruption of their time. Ibn Hijji cites the buying and selling of endowment assets, the diversion of their revenues from legal beneficiaries, and the use of endowed buildings as personal domiciles or renting them out for personal profit as proof of the degree to which the awqaf system had gone into decline. ${ }^{44}$ Mismanagement of this kind had direct financial and social consequences in cities like Damascus.

Urban officials were not the only ones to take advantage of the emerging opportunities offered by a growing waqf market. The most tangible response of local society to the increasing availability of formerly public lands was their purchase by members of the rural elite - local merchants, officials, and tribal leaders - and their subsequent endowment. The written sources that document a rise in rural endowments in Jordan among sultans and amirs in this period also attest to the development of private property among enterprising, and more affluent, members of local communities. Mamluk-era waqfiyat specify those properties, the revenues of which must be excluded from the endowment of lands for which the document was written, such as preexisting awqaf, both charitable and for families (mentioned in the documents by the family names), that are located within the borders of the estate described therein. ${ }^{45}$ For these preexisting endowments to have been made legally, they must have originally been the private property of the waqif.

There is supplementary documentary evidence for the growth in privately-owned, rural property in the late Mamluk period. Private land is referred to as such (milk) in the sixteenth-century tax registers described earlier. For Jordan, these are largely located in the region of Kerak, a phenomenon that still eludes explanation. The properties thus described are never very large: small plots of land (mazra'as, qit as) or shares in farmland, gardens, orchards, mills, houses, and shops. Some of the register entries document with certitude the status of these properties as privately held, potentially gaining for them tax-exemption, by including the date of "certification" (musadaqah) or "purchase" (tarikh al- mushtari). ${ }^{46}$ Most purchases were certified during the late fifteenth and early sixteenth century, thus at the

\footnotetext{
44. Yusuf Ghawanmeh, Dimashq, 111-116.

45. These properties, thus identified, are concentrated on the Kerak Plateau: for example, Waqfiyah \#49, microfilm \#15, folia 1-4, Dar al-Watha'iq, Cairo (mid-fifteenth century - for Sultan Khushqadam's Cairo madrasa); Waqfiyah \#40, microfilm \#15, folia 1-3, Dar al-Watha'iq, Cairo (dated 762/1361 - for Sultan Hasan's monumental madrasa complex in Cairo); and Waqfiyah 704, Wizarat al-Awqaf, Cairo (dated 14 Sha'ban 792/1390 for Barquq's mosquemadrasa complex in Cairo).

46. al-Bakhit and Hmoud, Tapu Defteri 185, 334-337. Taxable revenues for these milk lands are not included in the registers, suggesting they were exempt from at least kharaj. For the legal debates in early Ottoman Egypt on tax exemption of lands purchased from the Treasury, see Kenneth Cuno, “Miri or Milk?",122 and the section that follows.
} 
end of Mamluk rule. These entries reflect the requirement by Ottoman officials that taxpayers provide documentation of ownership, such as a purchase document, a requirement with which few could comply. ${ }^{47}$ We cannot know, though, whether these properties were purchased directly from the Treasury, although that is likely.

The registers, moreover, list numerous, though relatively modest, charitable endowments (for local mosques, shrines, and ribats), suggesting that much of the land acquired by local officials and families in the last century of Mamluk rule was converted into waqf. Although taxed by the Ottoman state (at the rate of 'ushr, rather than kharaj), it appears, at least for a while, that some of the endowments in Jordan were honored by the Ottoman government and remained in local hands, escaping confiscation. In short, once the opportunity to do so was recognized, the local elites took full advantage of the poor state of the Mamluk Treasury to acquire land for themselves and safeguard it through endowment.

\section{The legal establishment}

Kenneth Cuno describes the endowment of Treasury land as "an important factor in the economic and social life of the Islamic Middle East", and certainly the degree to which the alienation of public lands dominated debates by the legal scholars of the day indicates the importance of this phenomenon on many levels. ${ }^{48}$ The context of the debates centered on the disappearance of small, peasant holdings since the early Islamic period and their eventual replacement with large estates, under nominal state control, a process described by Johansen as the "sultanization of the awqaf". ${ }^{49}$ By the end of the Mamluk period, an alarmingly large portion of Treasury land had become privately owned through the transformation of iqta at into milk, the purchase of land or tax rights from the Treasury, and the giving away of state lands by the sultan to others as milk. ${ }^{50}$ Two Sunni madhhabs in particular, the Shafi'i and Hanafi, questioned whether such practices were in the interest of their communities or legal at all. Such debates were not mere intellectualisms; they transformed the legal orientations of their respective schools and helped to mold public opinion about the role of the state in the rural sector and the nature of its relationships with peasants, in particular, and the land.

What was at stake here was not control over public lands: this was the clearly the prerogative of the sultan and supported by most lawyers. Technically, "ownership" and

47. Baber Johansen, The Islamic Law on Land Tax and Rent: The Peasants' Loss of Property Rights as Interpreted in the Hanafite Legal Literature of the Mamluk and Ottoman Periods (London, 1988), 81-82, 87-88; Cuno, "Was the Land of Ottoman Syria Miri or Milk?, 127-128.

48. Cuno, "Ideological and Juridical Discourse", 146. The following pulls on arguments made in ibid; Johansen, Islamic Law on Land Tax and Rent; Cuno, "Miri or Milk?"; Martha Mundy, "ownership or office? A debate in Islamic Hanafite jurisprudence over the nature of the military 'fief', from the Mamluks to the Ottomans", in Law, Anthropology, and the Constitution of the Social: Making Persons and Things, ed. Alain Pottage and Martha Mundy (Cambridge, 2004), 142-165; and Martha Mundy and Richard Saumarez Smith, Governing Property, Making the Modern State: Law, Administration and Production in Ottoman Syria (London, 2007), 11-20.

49. Johansen, Islamic Law on Land Tax and Rent, 82.

50. Ibid., 81. 
usufruct of agricultural land were subject to law, but how that law functioned was a matter of negotiation between proprietors (muqta's and their agents), waqf administrators, and peasants. These relationships are described in some detail in Egyptian and Syrian fatwas of the fifteenth through eighteenth centuries. They are very useful, in this regard, for documenting legal developments (and political-economic realities) and changes in the fortunes of peasants, as well as measuring the pulse of public opinion as expressed by the ulama. In the late Mamluk and Ottoman periods this socio-economic class had become a body of "rentiers" who occupied a special position in the Mamluk state apparatus, rooted in both the cities and countryside. As recipients of stipends from endowed institutions, they had much to lose from attempts by the Ottoman government to incorporate awqaf assets back into the Treasury after the conquest of Egypt and Syria. Much of the debate in sixteenth-century fatwas about the legality of sultanic awqaf supports the claims of this class to former Treasury revenues.

In the late Mamluk period, debates centered on the general legality of alienating public (Treasury) lands through sale and endowment. Fatwas of this period focused on the conditions and under what circumstances such action was in the best interest of the Muslim community, through funding religious or public works or responding to emergencies. Ottoman fatwas on the same topic were more concerned with issues of taxation - whether it was legal for the state to tax (or confiscate) endowments made from former Treasury lands - having reached a general consensus at that point that the endowments in question were, in fact, legal. Different opinions by Shafi'i and Hanafi muftis on both issues reflect basic differences in the way they traditionally understood land tenure.

The Shafi'i was the highest ranking madhhab of the Mamluk state. While the Mamluks did appoint four chief judges from each of the Sunni schools, only the chief qadi of the Shafi $i$ school had the right to appoint deputy judges in the provinces, supervise the properties of orphans, and, most importantly, oversee the management of endowments. In this latter capacity, and as the privileged school in the Mamluk state, it had to rule on the legality of endowments made from Treasury lands. ${ }^{51}$ The majority of the populations of Syria and Egypt belonged to this school. Most of the Mamluk elite, however, ascribed to the Hanafi school, which later became the official madhhab of the Ottoman state.

The two schools originally differed in their opinions about Treasury assets because of fundamental differences in how they understood the "ownership" of Egyptian and Syrian land. For the Hanafis, Egypt and Syria, like Iraq, had been conquered by Muslim forces in the seventh century (taken by force and not treaty), and were thus subject to the kharaj tax. Nonetheless, the land remained in the hands of the previous owners: as long as taxes were paid, private ownership was honored, and the land could be sold and bequeathed by the proprietors at will. In short, the classical Hanafi view supported private ownership of land from the start. The Shafi is, by comparison, claimed conquered land automatically fell to the Treasury, and was administered by the ruler on behalf of the Muslim community as a whole. All agricultural land thus acquired the status of a collective waqf for all Muslims.

51. Cuno, "Ideology and Juridical Discourse", 148. 
In classical Shafi' $i$ thought, the state "owned" all land (the revenues of which resided in the Bayt al-Mal), and so long as the ruler acted in the best interest of Muslims, he could sell Treasury assets. Moreover, any endowments made from such land that was purchased from the Treasury through "traditional" channels were fully legal. Shafi i doctrine, in this sense, fully served the interests of the Mamluk state. For Hanafi's, land was in private ownership and only entered the Treasury if it was "sequestered" by the state (creating the category of aradi al-hawz), when the owners failed to pay their taxes or abandoned their fields, or when the owners died without heirs. Only in the latter case would land permanently enter the Treasury, and the ruler could sell it from there when it was needed. In order to explain how land that was once privately owned by peasants came under the complete control of the state, the Hanafis developed the concept of the "death of the proprietors", which maintained the fiction that at some point all land owners in Egypt had died intestate, and that the state had acquired legal rights over their properties as a result. As the owners of such land, the state (or the ruler as the agent of the state) had the right to sell and endow its own assets. Thus, over the course of the late Mamluk period Hanafi opinion gradually came to conform to that of the Shafi' is in regards to the legality of the alienation of public lands. Both, however, agreed that assets were best retained in the Treasury and that only when in the best interest (maslaha) of Muslims could they be sold, awarded in grants, or endowed. ${ }^{52}$

Not all lawyers, however, supported such conclusions, considering them mere acknowledgements of the status quo. Some contemporaries challenged the collective wisdom of the legal establishment on the basis that many practices connected to the Treasury harmed the state and did not serve the best interests of Muslims. One of the most vocal critics of management of the Treasury by the later Mamluk and early Ottoman sultans was the Shafi'i scholar Taqi al-Din Abu Bakr Muhammad ibn Muhammad alBalatunusi (lived 851-936/1448-1529), whose Tahrir al-Maqal fi-ma yahrim min Bayt al-Mal, a collection of fatwas completed in $871 \mathrm{H}$, provides a Syrian perspective on corruption and illegalities in the financial sphere, much like al-Asadi's work. ${ }^{53}$ This treatise is important on many levels. Chronologically, it spans the late Mamluk and early Ottoman transition, critiquing practices that were developing over the course of the early sixteenth century. Intellectually, it owes much to a network of Syrian scholars who lived in Damascus but had family roots in Jordan and maintained professional ties there.

The details of these networks are beyond the scope of this paper, and are explored elsewhere.$^{54}$ Nonetheless, they do reflect a heritage born of rural roots, with an interest in, and knowledge about, the resources and peoples of the countryside, and are thus relevant to this study. ${ }^{55}$ Al-Balatunusi was a Shafi'i scholar in Damascus, who was influenced by

52. Joseph H. Escovitz, “The Establishment of Four Chief Judgeships in the Mamluk Empire”, Journal of the American Oriental Society 102.3 (1982): 529-531; Cuno, "Miri or Milk?”, 123-125; and idem, "Ideology and Juridical Discourse”, 147-149.

53. I refer hereafter to Fath-Allah Muhammad Ghazi al-Sabbagh's edition of this work (1989, Cairo).

54. Walker, Jordan in the Late Middle Ages, in chapters 1 and 4.

55. Compared to the Hanafi scholars of Ottoman Egypt and Syria examined by Cuno and Mundy in the articles cited previously, these lawyers seem to have less a vested interest in maintaining endowments from Treasury lands for their own salaries. 
the work of Ibn Qadi Shuhba (d. 851/1448), Chief Qadi of Damascus in the 1430 s. $^{56}$ As a younger man, al-Balatunusi studied under two Damascus-born scholars who traced their family to a center of jurisprudence in Jordan: Taqi al-Din ibn Qadi Ajlun (d. $928 \mathrm{H}$ ) and Najm al-Din ibn Qadi Ajlun (d. $876 \mathrm{H}$ ). Among his own students were those whose family origins were also in Ajlun, as well as the small town of Salt, in central Jordan..$^{57}$ As many of his colleagues claimed a Jordanian background (though going back a few generations), so did his academic genealogy. Ibn Qadi Shuhba was a student of the Ibn Hijji al-Husbani (d. $816 \mathrm{H})$ mentioned earlier. ${ }^{58}$ Although a Shafi'i lawyer in Damascus, and born into a family of lawyers like Ibn Qadi Shuhba, Ibn Hijji apparently still had relatives in Jordan and maintained closer ties with Jordanian villages than even his nisba ("from Hisban") would suggest. He regularly visited villages in northern and central Jordan and corresponded on a regular basis with local scholars; his chronicle pulls heavily from these letters and demonstrates a real compassion for the suffering of the people living there. Tahrir al-Maqal, likewise, is ultimately concerned with justice for the rural and urban poor and communal access to land. Land is a precious resource, and its revenues belong to all Muslims.

Al-Balatunusi wrote his treatise, on the one hand, to chastise his colleagues in the legal profession, and on the other, to encourage them to discover how such practices got out of control, in an effort to address them. ${ }^{59} \mathrm{He}$ repeatedly refers to the alienation of public lands as bid'a (illegal innovation) and fasad (immorality or corruption); the work essentially concludes that, in contrast to the general consensus of his contemporaries, the sale of Treasury land was illegal. He rejects the reasons used by imams (sultans) for dipping into the Treasury. ${ }^{60}$ Treasury lands, in al-Balatunusi's mind, cannot be sold for emergencies, such as a drought, famine, or military campaign: it is better to establish a legal waqf that will serve these purposes in perpetuity. It cannot be sold to respond to unexpected circumstances, such as the sudden need to build mosques, canals, dams, and bridges at a time when the Treasury is low or empty: in such cases assets can be merely borrowed, temporarily, from the Treasury and must be returned when the crisis passes. ${ }^{61}$ Financial exigencies should never be met by using up Treasury funds.

He further argues that the Treasury is a sacred trust for the benefit of the Muslim community as a whole (masalih al-muslimin, li-maslahah 'amah) and belongs to no single individual, whether a sultan, amir, or civilian official. Sales and endowments made from it were a form of theft from the public. He bemoans the fact that soldiers came to think of their iqta's and the rulers of the Treasury as their private property, which they could

56. Joseph Schacht, "Ibn Kadi Shuhba", Encyclopaedia of Islam 4 (1971): 814.

57. Tahrir al-Maqal, 48-54.

58. His full name is Abu al-'Abbas Ahmad ibn Hijji al-Sa'idi al-Husbani al-Dimashqi. For his biography, see Tarikh Ibn Hijji, ed. Abu Yahya 'Abdallah al-Kandari (Beirut, 2003), 11-16 and Sami G. Massoud, An Analysis of the Annalistic Sources for the Early Mamluk Circassian Period, Vol. One, Ph.D. diss., McGill University (Montreal, 2005), 179-180. the latter has recently been published as The Chronicles and Annalistic Sources of the Early Mamluk Circassian Periode (Leiden, 2007).

59. Tahrir al-Maqal, 87.

60. Ibid., 242.

61. "wa al-istaqrad ila an yahsulu fi Bayt al-Mal fa la yajuzu al-bay" (Ibid., 240-241). 
bequeath; the injustice of the political leadership, the corruption of the ulama, and the general ignorance of the population led to this state of affairs. According to al-Balatunusi, everyone wanted a piece of the Treasury for himself:

"And everyone rushed to claim what they could from the Treasury and other places. People struggled and competed ever more in this until the Treasury was transformed into private property, endowments, and income (rizq). These, in turn, were transformed, by trickery, into personal estates that could be passed down to their families". ${ }^{62}$

For al-Balatunusi, the issue was less about the act of endowment than about who benefited from it. He specifically condemns those practices that allow individuals not entitled to Treasury funds to collect revenues from endowments made from Treasury assets. The poor should be the ultimate recipients, as they were legally entitled (mustahiqqun bi al-shar') to kharaj revenues. If endowed from the Treasury, family awqaf were illegal, as were those for Sufi institutions (funding shrines was batal) and endowments that served special groups, other than the ulama. Confirming his Shafi' $i$ heritage on this point, he emphasizes throughout his work that Treasury assets are a kind of waqf for all Muslims.

There were, as well, Hanafi voices that expressed concern about the privatization of public resources. Hanafis' opinions about land ownership changed significantly over the course of the fourteenth through sixteenth centuries, during which time they gradually abandoned their traditional support for small-scale, private ownership. The most influential work in this regard, Ibn al-Humam's Sharh fath al-qadir li-l-'ajiz al-faqir, while later cited as justification for these changing views, actually condemns both state monopolies over land and the alienation of the same from the Treasury. ${ }^{63} \mathrm{Kamal}$ al-Din Muhammad ibn 'Abd al-Wahid ibn al-Humam (1388-1457) was the first scholar of his madhhab to articulate a doctrine of land ownership based on the concept of the "death of the kharaj-payer", which he adopted to explain to himself the disappearance of peasant land ownership rights and the appearance of large landed estates. According to Ibn al-Humam, the land of Egypt used to be kharaj-paying, thus, privately-owned. This was no longer the case, however, in his day, leading him to suggest that it was as if all the land owners (kharaj-payers) had died intestate, leaving their property to the state. ${ }^{64}$ The concept was a valid one legally and made sense, in a limited sense, historically, considering the fate of the properties of victims of the Black Death. As a recognized legal category, land that fell to the Treasury in the absence of legal heirs could be sold by the state to new owners. The idea that all kharaj tax-payers had died without heirs was taken literally by subsequent generations of Hanafi scholars and adopted by them to justify state control of nearly all land under the Mamluks, as well as the alienation by the same from the Treasury. ${ }^{65}$

\footnotetext{
62. Ibid., 105.

63. Here I use the Beirut edition of his work, published in 1986.

64. Ibn al-Humam, Fath al-Qadir, 5:282.

65. For analyses of the impact of this work on Ottoman legal thought, see Johansen, Islamic Law on Land Tax and Rent, 85 ff; Cuno, “Ideology and Juridical Discourse”, 149 ff; idem, “Miri or Milk?', 122 ff; and Mundy and Smith Governing Property, 12-39.
} 
It is clear that he did not approve of the latter practice, claiming that Treasury assets were a sacred charge and should be treated carefully by the ruler:

"It is not permissible for the Imam to buy or sell anything from the Treasury, because responsibility for caring for Muslims' money is like the responsibility of an orphan's guardian. He is not allowed to sell from [his ward's] property, except in times of greatest need and there being no other way to support him."

As for the practice of a sultan buying Treasury land, he only reluctantly concedes, as in the case of orphans, only on the condition that there is demonstrable need for the sale to support the Muslim community. ${ }^{66}$ For Ibn al-Humam, like al-Balatunusi, Muslims' interests were best served by keeping assets in the Treasury.

\section{CONCLUSIONS}

We cannot know what long-term results these practices would have ultimately produced, as the Ottoman conquest interrupted the process of privatization, accelerated by the last Mamluk sultans. However, their potential is indicated by the early Ottoman tax registers, which document the continued productivity through the sixteenth century of estates in Jordan endowed from Treasury lands during the fourteenth. ${ }^{67}$ Through the Ottomans' investment in and providing security for them, former Mamluk endowments, at least for a time, were lucrative, taxable assets, whether as governorial khass or amiral timars. Perhaps these larger landed estates - contiguous plots of land under a single proprietor - could be more efficiently managed and taxed, and at less operating expense, than dispersed iqta'at or small, privately-owned gardens and shares of land. ${ }^{68}$ Regardless, the Ottomans maintained the largest of the rural endowments in Jordan for the simple reason that they guaranteed considerable tax revenues.

It remains to be seen how characteristic of Bilad al-Sham as a whole the changes in land proprietorship identified in Jordan were. One should see similar patterns in the rest of Syria. The reasons for such an early and extensive transformation of state lands to awqaf in the Transjordan still remain to be explained, although the arguably greater availability of land following the Black Death and the demonstrated fluidity of the local administrative structure may have made the process here easier than anywhere else. As for the local dimension of agrarian change, much is to be learned about peasants' responses to the land reforms of the Tanzimat era. The application of the 1858 Land Law requiring registration of land, for tax purposes, facilitated the creation of large, privately owned landed estates. The nineteenth-century grain boom in southern Syria would not have been possible without this development. ${ }^{69}$ Jordanians in the fifteenth century, like those in the nineteenth, made calculated decisions about land with an eye to both tradition and profitability. They

66. Ibn al-Humam, Fath al-Qadir, 5:283.

67. Walker, “Sowing the Seeds of Rural Decline?”, 193-195.

68. Ibid., 186-187.

69. Ibid., 187; idem, "Regional Markets and their Impact on Agriculture in Mamluk and Ottoman Transjordan" in On the Fringe of Society: Archaeological and Ethnoarchaeological Perspectives on Pastoral and Agricultural Societies, ed. Benjamin A. Saidel and Eveline J. van der Steen (Oxford, 2007), 117-125. 
took full advantage of opportunities to regain control over it, in both management and proprietorship, when state monopolies over "public" lands waned. The alienation of state lands in the late Mamluk period, while it was devastating to the Treasury, was profitable to many segments of Syrian society. 